\title{
Spectrophotometric Determination of Nickel with Chlorophosphonazo-III
}

\author{
XIAO-DONG LI $^{* 1}$ and QING-ZHOU ZHAI ${ }^{2}$ \\ ${ }^{1}$ Key Laboratory of Songliao Aquatic Environment, Ministry of Education, Jilin Jianzhu \\ University, 5088 Xincheng Street, Changchun 130118, JiLin Province, P. R. China \\ ${ }^{2}$ Research Center for Nanotechnology, Changchun University of Science and Technology, \\ Changchun 130022, 7186 Weixing Road, P. R. China \\ dxiaoli@163.com
}

Received 26 December 2013 / Accepted 23 January 2014

\begin{abstract}
The optimum conditions for spectrophotometric method for the determination of $\mathrm{Ni}^{2+}$ with chlorophosphonazo-III (CPA-III) were established and the nickel content in water samples has been successfully determined. In a pH 5.5 acetic acid-sodium acetate buffer medium, CPA-III and $\mathrm{Ni}^{2+}$ formed a 1:3 green blue complex and the maximum absorption wavelength of the complex is at $620 \mathrm{~nm} . \mathrm{Ni}^{2+}$ content in a range of $0.1 \sim 3.5 \mu \mathrm{g} / \mathrm{mL}$ and absorbance shows a good linear relationship. The apparent molar absorption coefficient of method is $\varepsilon_{620 \mathrm{~nm}}=1.40 \times 10^{4} \mathrm{~L}$ $\mathrm{mol}^{-1} \mathrm{~cm}^{-1}$ and the detection limit is $0.075 \mu \mathrm{g} / \mathrm{mL}$.
\end{abstract}

Keywords: Nickel, Chlorophosphonazo-III, Spectrophotometry, Water sample

\section{Introduction}

Nickel is one of the most common sensitizing metals and about $20 \%$ of the people are allergic to nickel ion. In contact with the human body, nickel ion can penetrate inside the skin by pores and sebaceous glands, thus causes skin allergic inflammation and its clinical manifestations are dermatitis and eczema. The clinical manifestations of nickel allergic dermatitis are itching papular, papular or papulovesicular dermatitis, accompanying moss. Similar with other elements, nickel is regulated and controlled by the internal balance mechanism of body. Intake amount is too low, which will result in element deficiency symptom. Nickel is a trace element essential to the human body and it can make the increase of insulin and the blood glucose decrease. However, excessive intake will accumulate in the organism and acute, chronic poisoning appears and even the excessive nickel can become a potential carcinogen ${ }^{1}$. Humans can absorb nickel through drinking water way etc. Therefore, development of an analytical method for the determination of nickel has a very important practical value.

Some methods for the determination of nickel have been proposed, which involved atomic absorption spectrometry ${ }^{2}$, inductively coupled plasma-atomic emission spectrometry ${ }^{3}$ 
X-ray fluorescence spectrometry ${ }^{4}$, inductively coupled plasma-mass spectrometry ${ }^{5}$, etc. However, for these methods the instruments are expensive and the analysis costs are high. Spectrophotometry has the characteristic that instrument is cheaper, operation is simple and convenient and is a determination method of higher practical value. Chlorophosphonazo-III (abbreviated as: CPA-III), has been ever used as rare earths ${ }^{6}$, magnesium ${ }^{7}$ chromogenic agent. To the best of our knowledge, no study report on chromogenic reaction of the reagent and nickel(II) is seen. In this paper, color reaction of the reagent with nickel(II) was studied and successfully applied to the determination of nickel in water samples.

\section{Experimental}

Absorbance was measured on a 722S spectrophotometer (Shanghai Lenggunag Technique Co., Ltd., China) with $1 \mathrm{~cm}$ cells. The stock standard solution of nickel, $1 \mathrm{mg} / \mathrm{mL}$, was prepared by dissolving $0.4784 \mathrm{~g}$ of $\mathrm{NiSO}_{4} \cdot 7 \mathrm{H}_{2} \mathrm{O}$ (Beijing Chemical Works, China) in an appropriate amount of water containing $2 \mathrm{~mL}$ of $\mathrm{H}_{2} \mathrm{SO}_{4}(1+1, \mathrm{~V} / \mathrm{V}$, Beijing Chemical Works, China) and then diluted to $100 \mathrm{~mL}$ with water. A $10 \mu \mathrm{g} / \mathrm{mL}$ of working solution of nickel(II) was prepared by diluting the stock solution with water. Chlorophosphonazo-III (CPA-III, Shanghai Changke Research Institute of Reagent, China) solution, $1 \mathrm{~g} / \mathrm{L}$, was used. Buffer solution $(\mathrm{pH}=5.5)$ was prepared by mixing $0.1 \mathrm{~mol} / \mathrm{L}$ acetic acid (Beijing Chemical Works, China) and $0.1 \mathrm{~mol} / \mathrm{L}$ sodium acetate (Beijing Chemical Works, China) according to the volume ratio of 1:20. Unless otherwise stated, all reagents used in the experiment were of analytical-reagent grade and the water was distilled.

\section{General procedure}

In a $10 \mathrm{~mL}$ calibrated flask, $20 \mu \mathrm{g} \mathrm{Ni}(\mathrm{II})$ working solution, $1.5 \mathrm{~mL}$ of chlorophosphonazo-III solution, $2.0 \mathrm{~mL}$ of buffer solution were added and diluted to the mark with water. After standing for $5 \mathrm{~min}$, the absorbance was measured at $620 \mathrm{~nm}$ in a $1 \mathrm{~cm}$ cell against a reagent prepared in the same way but without $\mathrm{Ni}(\mathrm{II})$.

\section{Results and Discussion}

\section{Absorption spectra}

Chlorophosphonazo-III presents violet in $\mathrm{pH}=5.5 \mathrm{HAc}-\mathrm{NaAc}$ medium, while it can form a green blue complex with nickel(II) under the condition. The maximum absorption wavelength of the complex against reagent blank is at $620 \mathrm{~nm}$ (Figure 1), while that of the reagent blank against water is at $550 \mathrm{~nm}$. In this study, $620 \mathrm{~nm}$ was used as the determination wavelength in order to obtain maximum sensitivity.

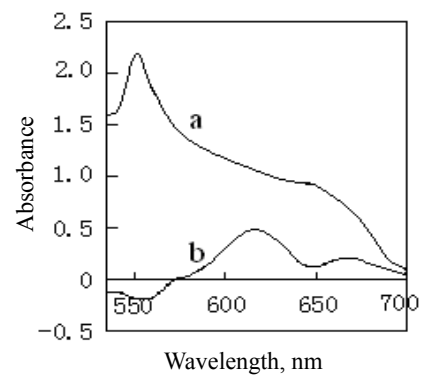

Figure 1. Absorption spectra: (a) Reagent blank (against water); (b) complex (against reagent blank); $\left[\mathrm{Ni}^{2+}\right]=3.4 \times 10^{-5} \mathrm{~mol} / \mathrm{L} ; \mathrm{pH}=5.5$ 


\section{Optimization of experimental variables}

The results of acidity effect showed that a maximum and constant absorbance could be obtained over the $\mathrm{pH}$ 5.0-6.5. Thus, $\mathrm{pH} 5.5$ was selected. In $10 \mathrm{~mL}$ of solution, $1.8-2.2 \mathrm{~mL}$ HAc-NaAc buffer solution gave a constant and maximum absorbance, therefore $2.0 \mathrm{~mL}$ is recommended.

With the addition of $1.0-2.0 \mathrm{~mL}$ of $1 \mathrm{~g} / \mathrm{L}$ chlorophosphonazo-III solution, absorbance was maximum and the sensitivity was the highest. So determinations were carried out with $1.5 \mathrm{~mL}$ of chlorophosphonazo-III solution.

The experimental results displayed that the order of reagent addition had no effect on the absorbance of this system. This study used the order of Ni(II) + CPA-III + HAc-NaAc buffer solution.

\section{Complex composition ratio and stability}

By means of molar-ratio method and equimolar continuous variation method, the composition of the complex was determined to obtain the composition ratio of the complex as (CPA-III): $\mathrm{Ni}(\mathrm{II})=3: 1$. At room temperature, the color reaction was immediately completed. When $2.0 \mu \mathrm{g} / \mathrm{mL} \mathrm{Ni(II)} \mathrm{was} \mathrm{determined,} \mathrm{within} 2 \mathrm{~h}$ the absorbance variation was less than $5 \%$ and the complex remain stable.

\section{Working curve}

At the maximum absorption wavelength of $620 \mathrm{~nm}, \mathrm{Ni}^{2+}$ content in the range of $0.1 \sim 3.5 \mu \mathrm{g} / \mathrm{mL}$ and the absorbance A showed a good linear relationship and its linear regression equation is $\mathrm{A}=0.1647 \mathrm{C}(\mathrm{g} / \mathrm{mL})+0.0073$ with a correlation coefficient of 0.9993. The apparent molar absorption coefficient of method was $\varepsilon_{620 \mathrm{~nm}}=1.40 \times 10^{4} \mathrm{~L}$. $\mathrm{mol}^{-1} \mathrm{~cm}^{-1}$. According to the general procedure 11 parallel determinations of $2.00 \mu \mathrm{g} / \mathrm{mL}$ of $\mathrm{Ni}$ (III) were made and the average value determined was $2.03 \mu \mathrm{g} / \mathrm{mL}$. The relative standard deviation of the determined results was $1.2 \%$. For 11 determinations of reagent blank, based on $\rho=3 \mathrm{~S} / \mathrm{K}$ ( $\mathrm{S}$ is the standard deviation of eleven parallel determinations of reagent blank, $\mathrm{K}$ is the slope of working curve), the detection limit of the method was calculated to be $0.075 \mu \mathrm{g} / \mathrm{mL}$.

\section{Selectivity of method}

An extensive study was made of the effect of foreign ions in the determination of $2.0 \mu \mathrm{g} / \mathrm{mL}$ $\mathrm{Ni}(\mathrm{II})$ under the optimum experimental conditions. The tolerance (5\% error maximum) to foreign ions is as follows (W/W) : $\mathrm{F}^{-} 、 \mathrm{Cl}^{-} 、 \mathrm{Br}^{-} 、 \mathrm{CH}_{3} \mathrm{COO}^{-} 、 \mathrm{SiO}_{4}{ }^{2-} 、 \mathrm{SO}_{4}{ }^{2-} 、 \mathrm{PO}_{4}{ }^{3-}(100)$, $\mathrm{B}(\mathrm{III}), \mathrm{I}^{-}(50), \mathrm{Ag}^{+}, \mathrm{Cd}^{2+}(15) ; \mathrm{Mg}^{2+}(4), \mathrm{Cu}^{2+}, \mathrm{Al}^{3+}, \mathrm{Fe}^{3+}, \mathrm{Y}^{3+}, \mathrm{Zr}^{4+}(0.5): \mathrm{Ce}(\mathrm{IV})$, $\mathrm{Mo}(\mathrm{VI})$ (0.4); $\mathrm{Cr}(\mathrm{VI})(0.3) ; \mathrm{Fe}^{2+}, \mathrm{Zn}^{2+}, \mathrm{W}(\mathrm{VI})(0.2)$; $\mathrm{Ti}(\mathrm{IV})(0.1) ; \mathrm{Co}^{2+}, \mathrm{Mn}^{2+} \mathrm{MnO}_{4}^{-}(0.05)$; $\mathrm{Ca}^{2+}, \mathrm{Sr}^{2+}, \mathrm{Ba}^{2+}, \mathrm{La}^{3+}, \mathrm{Y}^{3+}(0.02)$.

\section{Sample analysis}

$500 \mathrm{~mL}$ of rain water was taken and heated for concentration to about $50 \mathrm{~mL}$. After cooling, $5 \mathrm{~mL}$ of aqua regia was added to it. The contents were evaporated on an electric cooker to near dryness, dissolved by a small amount of water, transferred to a $10 \mathrm{~mL}$ calibrated flask and determined for nickel according to the general procedure. Meanwhile, atomic absorption spectrometry was used as contrast method for the determination of nickel content in the water sample. The above results are listed in Table 1. 
Table 1. Analytical results of samples

\begin{tabular}{ccccccc}
\hline Sample & $\begin{array}{c}\text { Found } \\
(\mathrm{n}=11) \\
\mu \mathrm{g} / \mathrm{g}\end{array}$ & $\begin{array}{c}\text { Relative } \\
\text { standard } \\
\text { deviation } \%\end{array}$ & $\begin{array}{c}\text { Added } \\
\mu \mathrm{g} / \mathrm{g}\end{array}$ & $\begin{array}{c}\text { Recovered } \\
\mu \mathrm{g} / \mathrm{g}\end{array}$ & $\begin{array}{c}\text { Recovery } \\
\%\end{array}$ & $\begin{array}{c}\text { Atomic absorption } \\
\text { spectrometry } \\
\mu \mathrm{g} / \mathrm{g}\end{array}$ \\
\hline No.1 & 37.9 & 2.3 & 5.000 & 5.002 & 100.04 & 37.9 \\
No.2 & 45.2 & 1.9 & 5.000 & 4.998 & 99.96 & 45.3 \\
\hline
\end{tabular}

\section{Conclusion}

A method for the spectrophotometric determination of nickel with chlorophosphonazo-III has been established. Beer's law was obeyed over the range of $0.1 \sim 3.5 \mu \mathrm{g} / \mathrm{mL}^{-1} \mathrm{Nor}^{2+}$. The apparent molar absorption coefficient of method was $\varepsilon_{620 \mathrm{~nm}}=1.40 \times 10^{4} \mathrm{~L} \cdot \mathrm{mol}^{-1} \mathrm{~cm}^{-1}$ and the detection limit was $0.075 \mu \mathrm{g} / \mathrm{mL}$. The recoveries for analyses of the rainwater samples obtained were $99.96 \%-100.04 \%$ and the relative standard deviations were $1.9 \%-2.3 \%$ with satisfactory results. The present method for determination of nickel is more convenient than the ones in literature ${ }^{2-5}$.

\section{Acknowledgment}

This work was financially supported by grants from Jilin Jianzhu University (Grant No. 865002(15) and 861063).

\section{References}

1. Cao H M, Lai H W, Dong S G and Zhu Z G, Guangdong Trace Elements Sci., 2006, 13(12), 1-6. (Chinese Edition)

2. Zou A L, Ren F L and Deng S L, Chin J Spectr Lab., 2002, 19(3), 349-353.

3. Zhang Chao and Li Xiang, Rock Miner Anal., 2011, 30(4), 473-476. (Chinese Edition)

4. Zhang J B, Lin L and Wang Q, Metallur Anal., 2008, 28(1), 15-19. (Chinese Edition)

5. Li J, Li J and Zhang S Z, Metallur Anal., 2011, 31(5), 16-19. (Chinese Edition)

6. Pan J M, Li Z J, Zhang Q Y and Fang G Z, New Chromogenic Reagents and Their Application in Spectrophotometry, Beijing: Chemical Industry Press, 2003, p.18.

7. $\quad$ Li X D and Zhai Q Z, Asian J Chem., 2013, 25(7), 4123-4124;

DOI:10.14233/ajchem.2013.14475B 